\title{
IDENTIFICATION OF STRIPE RUST RESISTANCE GENES Yr's IN CANDIDATE EGYPTIAN AND CIMMYT WHEAT GENOTYPES BY MOLECULAR MARKERS
}

\author{
Abu Aly, A.A.; A.A. Shahin; Doaa R. EL-Naggar and \\ M.A. Ashmawy \\ Wheat Disease Research Department, Institute of Plant Pathology, \\ Agriculture Research Centre Egypt. \\ E-mail: a_aziz_egypt2007@yahoo.com; a.a.shahin@hotmail.com
}

\begin{abstract}
Stripe rust is a widespread damaging disease of wheat, causing significant losses in yield and quality. Each monogenic line of Yr1, Yr5, Yr10, Yr15, Yr17, Yr32 and $Y r S P$ exhibited high levels of resistance to both 198 E56 and 128E28 races, at seedling stage. The same monogenic lines showed adult plant resistance. Whereas, those with Yr17 and YrSP showed a disease severity ranged between 5MR to 10MR. The monogenic line ( $Y r S K$ ) was the only one which recorded susceptible and highly resistant reactions, at seedling and adult stages respectively. Nine Egyptian cultivars and four lines from CIMMYT tested at seedling stage were susceptible (IT 6-8). Misr1, Misr-2, Gemmezia-10, Line-6043, Line-6085, Line-6086 and Line-6107 showed a range of adult plant responses of $\mathrm{TrR}-10 \mathrm{MR}$. The remainder had variable degrees of susceptibility (5MS-30S). Fourteen genotypes were screened with three DNA markers to detect the presence of Yr9, Yr17 and Yr18. The 1100bp band diagnostic for $Y r 9$ was present in 7 genotypes, i.e. Misr-1, Misr-2, Sids-12, Sids13, Gemmeiza-9, Gemmeiza-10 and Gemmeiza-11. At 252bp fragment in Line 6043 (8STEMRRS) from CIMMYT was only indicative of Yr17, and Yr18 was present all tested Egyptian and CIMMYT genotypes at 517bp.

Keywords: wheat, stripe rust, resistance gene, molecular marker.
\end{abstract}

\section{INTRODACTION}

Stripe rust of wheat, caused by Puccinia striiformis $f . s p$. tritici, is one of the most widespread and damaging diseases of wheat, causing great losses in yield and grain quality (Line, 2002; Chen, 2005). Grain losses caused by this devastating pathogen have been reported to be 10-70 percent (Chen, 2005).

The frequency of epidemics and damage caused by stripe rust is different in each country. In Egypt stripe rust is the most common and important wheat disease. It caused severe losses in grain yield (Abu ElNaga, et al., 2001). Lot of methods are available to control wheat rusts. One of them, the economical and environmentally safe protection of wheat against rusts, is possible by growing resistant wheat varieties. Otherwise, the most feasible method is host genetic resistance to control stripe rust. Utilization of genetic resistance is economical and carries no health and environmental hazards (Chen and Zhao, 2007).

To date more than forty three resistant genes at different loci have been designated and mapped to different wheat chromosomes. Most of genes are race- specific and cultivars possessing some of them played 
important role in wheat breeding (Cao et al., 2001; Mclntosh et al., 1996, 2004 and 2005). So far, studies have shown that Yr11, Yr12, Yr13, Yr14, Yr16, Yr18, Yr29, Yr30, Yr34, Yr36, Yr39, Yr46, Yr49 and Yr52 are adultplant resistance genes (Chen, 2005; Bariana et al., 2006; Cheng, 2008; Lowe et al., 2011; Ren et al., 2012), of which Yr18 and Yr36 have been cloned (Fu et al., 2009; Krattinger et al., 2009). Because adult-plant resistance (APR) genes only have partial effects when present alone, the resistance conferred by them may be incomplete.

The development of molecular markers for specific stripe genes allows the rust detection of these genes independently of the phenotype. Molecular markers can be used in marker-assisted selection for an efficient combination of genes in the pyramiding strategy to create a more durable resistance (Feuillet et al., 1995). Simple sequence repeats (SSR) or micro satellites are useful tools for molecular genetic analysis as they are more abundant and display higher levels of polymorphisms in many plant species (Hitta et al., 1995 and Plaschke et al., 1995). SSR markers i.e. Yr5, Yr10, Yr15, Yr24 and YrH52 have been reported for several stripe rust resistance genes (Peng et al., 1999, 2000; Sun et al., 2002; Wang et al., 2002; Zakari et al., 2003). Some markers have been used in marker-assisted selection and for pyramiding resistance genes as well as for understanding of the relationships among different genes.

Molecular markers not only allowed the easy and reliable identification of clones and breeding lines but also facilitated the monitoring of introgression and the estimation of genetic diversity and relatedness among germ plasma (Mukhtar et al., 2002). To date, many genes have been identified and located by SSR such as Yr5 (Sun et al., 2002), Yr17 (Robert et al., 2000), YrH52 (Peng et al., 1999 \& 2000-a and b), Yr26 (Ma et al., 2001), Yr15 (Sun et al., 1997), Yr28 (Singh et al., 2000) and Yr32 (Eriksen et al., 2000).

This study mainly aimed to identify the stripe rust resistance genes in some wheat cultivars from Egypt and promising lines from CIMMYT by traditional work and advanced method, molecular markers.

\section{MATERIALS AND METHODS}

\section{Plant material:}

In this study, different wheat genotypes were used containing fourteen stripe rust resistance genes (Yr1, Yr5, Yr6, Yr7, Yr8, Yr9, Yr10, Yr15, Yr17, Yr18, Yr27, Yr32, YrSP, and YrSK), nine Egyptian wheat cultivars (Misr-1, Misr-2, Gemmiza-9, Gemmiza-10, Gemmiza-11, Sakha-93, Sids-12, Sids-13 and Giza-171) and four promising wheat lines (6043, 6085, 6086 and 6107) from international trails nurseries obtained from the International Maize and Wheat Improvement Center (CIMMYT).

2. Evaluation for stripe rust resistance:

Wheat genotypes were tested for stripe rust resistance at seedling and adult plant stages. 


\section{Seedling stage:}

All plant materials were grown in plastic pots $(10 \mathrm{~cm}$ in diameter) in greenhouse in Sakha Agriculture Research Station. Each pot contained four entries clockwise in each corner. The method of inoculation was carried out as described by (Stakman et al., 1962). The inoculated plants were incubated in a dark dew chamber overnight at $10^{\circ} \mathrm{C}$ and $95 \%$ relative humidity then moved to the benches in the greenhouse and maintained at $12^{\circ} \mathrm{C}-15^{\circ} \mathrm{C}$ and $95-100 \%$ relative humidity. Light intensity was adjusted at 7600 lux in a photoperiod of 16 hours light and 8 hours dark (Stubbs, 1988). After approximately two weeks from inoculation, Infection types (IT's) on the plants $(0-9)$ were scored as described by (McNeal et al., 1971). Plants with IT's of 0,$0 ;, 1,2,3,4$ and 5 were considered as resistant response, while IT's of 6 , 7,8 and 9 were considered as susceptible response.

\section{Adult stage:}

Adult plant resistance was evaluated on the same set of materials in field during 2012/2013 and 2013/2013 growing seasons at Sakha agricultural research station, the recommended agricultural practices were applied. The inoculation of plants was carried out at booting stage according to the method of Tervet \& Cassell (1951). Disease severity was assessed using the modified Cobb's Scale (Peterson et al., 1948). Infection response was scored as resistant (R), moderately resistant (MR), moderately susceptible (MS) and susceptible (S), as described by Roelfs et al., (1992).

\section{Molecular markers: \\ DNA extraction:}

Total genomic DNA of each wheat cultivar and lines was extracted from leaves following the protocol described by Mago et al., (2002). Samples of $60 \mathrm{mg}$ leaf tissue were digested in liquid nitrogen with a mortar and pestle using i-genomic plant DNA extraction Mini Kit (iNtRON Biotechnology, Inc, Cat. No. 17371) according to manufacturer's instructions. The eluted DNA was stored at $-20 \stackrel{\circ}{ } \mathrm{C}$.

\section{PCR mixture for Yrgenes detection:}

PCR reaction was conducted in reaction volume of $(25 \mu \mathrm{l})$ contained, $(1 \mu \mathrm{l})$ of $25 \mathrm{ng}$ nucleic acid, $1 \mu \mathrm{l}$ of each primer $(10 \mathrm{pmol}),(12.5 \mu \mathrm{l})$ of GoTag $\AA$ Colorless Master Mix (Promega Corporation, USA) and $9.5 \mu \mathrm{l}$ of Nuclease free water (Promega). $15 \mu \mathrm{l}$ of all PCR products were analyzed by electrophoresis through a 1.5\% agarose gel, stained with ethidium bromide, and DNA bands were visualized using a UV transilluminator. Sequences of primers are listed in Table (1).

Table (1): List of the tested stripe rust resistance genes and their sequences of primers

\begin{tabular}{|l|l|l|}
\hline Yr gene & Sequence or Primer Pair & Reference \\
\hline \multirow{2}{*}{$Y r 9$} & F5' CTCTGTGGATAGTTACTTGATCGA 3' & Mago et al., 2002 \\
\hline Rr17 & F5' CCTAGAACATGCATGGCTGTTACA 3' & Helguera et al., 2003 \\
& R5'TGCAGCTACAGCAGTATGTACACAAAA 3' & Lagudah et al., 2009 \\
\hline \multirow{2}{*}{$Y r 18$} & F5'TTGATGAAACCAGTTTTTTTTCTA3' & \\
\hline
\end{tabular}




\section{RESULTS}

Data in Table (2) showed that Yr1, Yr5, Yr10, Yr15, Yr17, Yr32 and $Y r S P$, each at seedling and adult stages, exhibited high resistance against stripe rust reaction. At seedling stage, IT's for 198E56 and 128E28 races were ranged between 0-2. At adult stage, Yr1, Yr5, Yr10, Yr15 and Yr32 recorded complete resistance. While Yr17 and YrSP showed a disease severity ranged between $5 \mathrm{MR}$ to $10 \mathrm{MR}$.

Also, Table (2) indicated that single gene lines i.e. Yr6, Yr7, Yr8, Yr9 and $Y_{118}$ were susceptible $(I T=6-9)$ at seedling stage and were from 10MS to $70 \mathrm{~S}$, at adult stage. The monogenic line (YrSK) was the only one which recorded susceptible and highly resistant reactions, at seedling and adult stages respectively. Misr-1, Misr-2, Gemmezia-10, Line-6043, Line-6085, Line-6086 and Line-6107 showed a range of adult plant responses of TrR$10 M R$. The remainder had variable degrees of susceptibility (5MS-30S).

Table (2): Seedling response of monogenic lines, some Egyptian and CIMMYT wheat genotypes against two Puccinia striiforms races and their adult plant field reaction during 2012/2013 and 2013/2014 growing seasons.

\begin{tabular}{|c|c|c|c|c|}
\hline \multirow{2}{*}{ Genotype } & \multicolumn{2}{|c|}{ Seedling infection type } & \multicolumn{2}{|c|}{ Disease severity at the adult stage } \\
\hline & Race 128E28 & Race 198E56 & Second season & First season \\
\hline Yr1/6*Avocet $S$ & 0 & 0 & 0 & 0 \\
\hline Yr5/6*Avocet $S$ & 0 & 0 & 0 & 0 \\
\hline Yr6/6*Avocet $S$ & 7 & 8 & $50 S$ & $60 S$ \\
\hline$Y r 7 / 6^{*}$ Avocet $S$ & 7 & 9 & $70 S$ & $70 S$ \\
\hline Yr8/6*Avocet $S$ & 7 & 8 & $40 S$ & $60 \mathrm{~S}$ \\
\hline Yr9/6*Avocet $S$ & 6 & 7 & $40 S$ & $40 S$ \\
\hline Yr10/6*Avocet S & 0 & 2 & 0 & 0 \\
\hline Yr15/6*Avocet $S$ & 0 & 0 & 0 & 0 \\
\hline Yr17/6*Avocet $S$ & 1 & 2 & $5 \mathrm{MR}$ & 10MR \\
\hline Yr18/6*Avocet S & 6 & 7 & $10 \mathrm{MS}$ & $10 S$ \\
\hline Yr27/6*Avocet S & 3 & 4 & $5 \mathrm{MS}$ & $5 \mathrm{MS}$ \\
\hline Yr32/6*Avocet $S$ & 2 & 2 & 0 & 0 \\
\hline YrSP $/ 6^{\star}$ Avocet $S$ & 2 & 2 & $10 \mathrm{MR}$ & $10 \mathrm{MR}$ \\
\hline YrSK/6*Avocet $S$ & 7 & 8 & $5 \mathrm{MR}$ & 10MR \\
\hline Misr 1 & 7 & 8 & $5 \mathrm{MR}$ & $5 \mathrm{MR}$ \\
\hline Misr 2 & 7 & 7 & $5 \mathrm{MR}$ & $10 \mathrm{MR}$ \\
\hline Gemmeiza 9 & 8 & 7 & $10 S$ & $5 \mathrm{MS}$ \\
\hline Gemmeiza 10 & 7 & 8 & $10 \mathrm{MR}$ & $10 \mathrm{MR}$ \\
\hline Gemmeiza 11 & 7 & 7 & $10 \mathrm{MS}$ & $10 \mathrm{MS}$ \\
\hline Sakha 93 & 8 & 7 & 20MS & $30 S$ \\
\hline Sids 12 & 7 & 7 & $10 \mathrm{MS}$ & $30 S$ \\
\hline Sids 13 & 7 & 7 & 10MS & $10 \mathrm{MS}$ \\
\hline Giza 171 & 6 & 6 & 5MR-MS & $5 \mathrm{MS}$ \\
\hline Line 6043 & 6 & 6 & TrR & $5 R$ \\
\hline Line 6085 & 7 & 7 & $10 \mathrm{MR}$ & $5 \mathrm{MR}$ \\
\hline Line 6086 & 8 & 7 & $10 \mathrm{R}$ & $5 R$ \\
\hline Line 6107 & 6 & 7 & $5 \mathrm{MR}$ & TrMR \\
\hline
\end{tabular}

Thirteen genotypes were screened with three DNA markers aimed at detecting the presence of $Y r 9, Y r 17$ and Yr18. Figure (1) showed the polymorphic survey of $Y r 9$ gene marker which was identified as a fragment of 1100bp band in 7 genotypes (Misr-1, Misr-2, Sids-12, Sids-13, Gemmeiza-9, Gemmeiza-10 and Gemmeiza-11). The only indicative band for Yr17 was observed at $252 \mathrm{pb}$ fragment Line-6043 (8STEMRRS), as shown in Fig. (2). 
While, Yr18 was identified as a fragment of $517 \mathrm{pb}$ in all tested Egyptian and CIMMYT genotypes, Fig. (3). Data obtained from figures 1, 2 and 3 were summarized in Table (3).

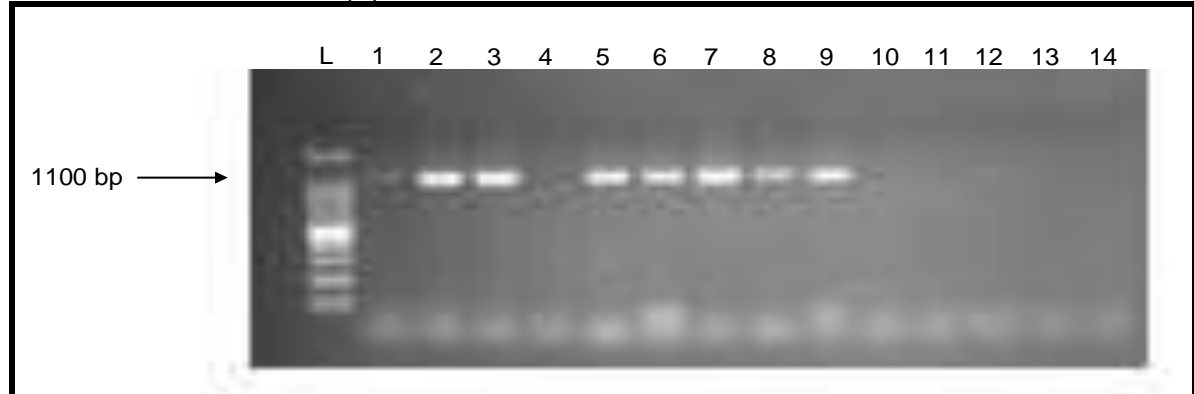

Fig. (1). Amplification products of $Y r 9$ marker using PCR in the tested wheat genotypes running on agarose gel. L: DNA Ladder, Lane (1): monogenic Yr9, (2): Misr-1, (3): Misr-2, (4): Sakha-93, (5): Sids-12, (6): Sids-13, (7): Gemmiza-9, (8): Gemmiza-10, (9): Gemmiza11, (10): Giza-171, (11): Line-6043, (12): Line-6085, (13): Line-6086 and (14): Line6107. The arrow shows the fragment which is associated with Yr9 at $1100 \mathrm{bp}$

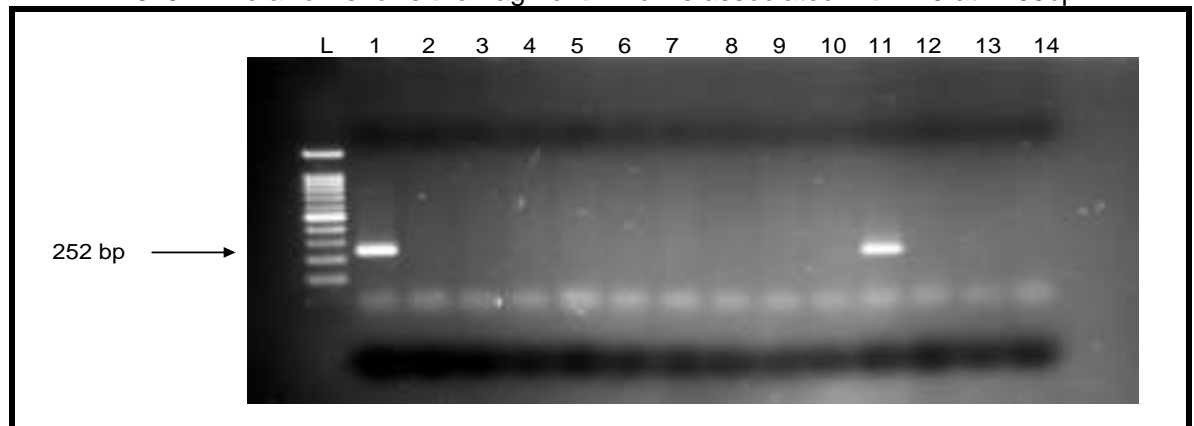

Fig. (2). Amplification products of Yr17 marker using PCR in the tested wheat genotypes running on agarose gel. L: DNA Ladder, Lane (1): monogenic Yr9, (2): Misr-1, (3): Misr-2, (4): Sakha-93, (5): Sids-12, (6): Sids-13, (7): Gemmiza-9, (8): Gemmiza-10, (9): Gemmiza11, (10): Giza-171, (11): Line-6043, (12): Line-6085, (13): Line-6086 and (14): Line6107. The arrow shows the fragment which is associated with Yr17 at 252bp.

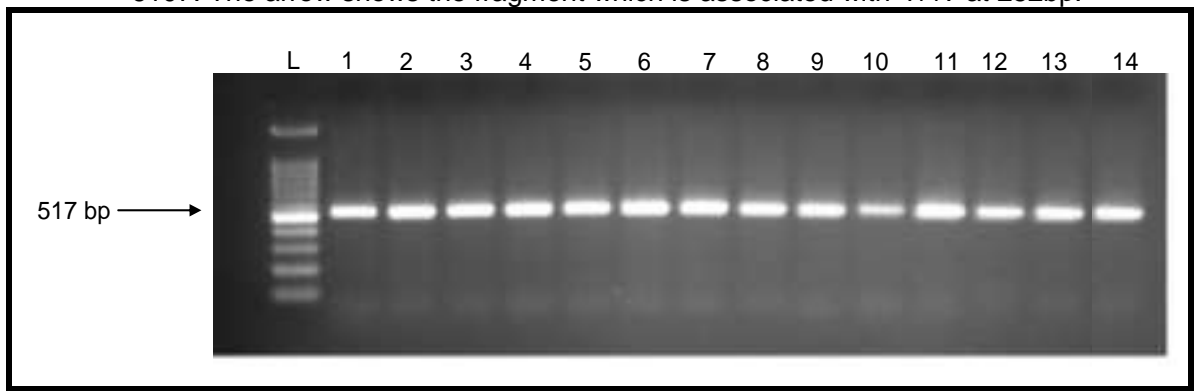

Fig. (3). Amplification products of Yr18 marker using PCR in the tested wheat genotypes running on agarose gel. L: DNA Ladder, Lane (1): monogenic Yr9, (2): Misr-1, (3): Misr-2, (4) Sakha-93, (5): Sids-12, (6): Sids-13, (7): Gemmiza-9, (8): Gemmiza-10, (9): Gemmiza11, (10): Giza-171, (11): Line-6043, (12): Line-6085, (13): Line-6086 and (14): Line6107 . The arrow shows the fragment which is associated with Yr18 at 517bp. 
Table (3): Yr genes detected with PCR based markers in nine Egyptian wheat cultivars and four CIMMYT wheat lines.

\begin{tabular}{llccc}
\hline No. & Genotypes & Yr9 & Yr17 & Yr18 \\
\hline 1 & Misr-1 & + & - & + \\
2 & Misr-2 & + & - & + \\
3 & Gemmeiza-9 & + & - & + \\
4 & Gemmeiza-10 & + & - & + \\
5 & Gemmeiza-11 & + & - & + \\
6 & Sakha-93 & - & - & + \\
7 & Sids-12 & + & - & + \\
8 & Sids-13 & + & - & + \\
9 & Giza-171 & - & + & + \\
10 & Line-6043 & - & - & + \\
11 & Line-6086 & - & - & + \\
13 & Line-6107 & - & - & + \\
\hline
\end{tabular}

\section{DISCUSSION}

Stripe rust is one of the most important diseases of wheat occurring almost in all wheat-producing regions causing crop yield reduction. In order to produce resistant cultivars, it is necessary to identify resistance genes in different germplasms. The objective of this study was to develop a set of public PCR assays for an efficient selection of resistance genes in wheat breeding programs.

The Yr9 gene was identified in the tested cultivars but was not effective in Egypt. The 1100 bp band diagnostic for $Y r 9$ was present in 7 genotypes i.e. Misr-1, Misr-2, Sids-12, Sids-13, Gemmeiza-9, Gemmeiza-10 and Gemmeiza-11. Due to the lack of pairing between the wheat and rye chromatin (1B and 1BL.1RS) in the wheat background, Sec-1 acts as a marker for Lr26, Yr9 and Sr31. Studies done by Afshari (2004) indicated that the eight wheat cultivars, except for Alamoot cultivar, have shown good levels of stripe rust resistance in Iran. The 1BL.1RS segment carries genes for resistance to three rusts, namely Lr26, Yr9, Sr26, and gene Pm8 for resistance to powdery mildew (Zeller 1973).

To date, a number of resistance genes have been introduced into wheat from relatives (Friebe et al., 1996; Fedak, 1999). Wheat stripe rust resistance gene, Yr17, in combining with Lr37 (for resistance to leaf rust caused by Puccinia triticina Eriks) and Sr38 (for resistance stem rust caused by Puccinia graminis $f$. sp. tritici Eriks. \& E. Henn.) were initially introgressed in wheat variety 'VPM1' from Aegilops ventricosa Ces. (Maia, 1967) and were located on a 2NS/2AS translocation (Bariana and Mclntosh, 1993 \& 1994). Although new emerged rust races with virulence to Yr17 have been identified in different countries, this gene in combination with other rust resistance. At 252bp fragment in Line 6043 (8STEMRRS) from CIMMYT was only indicative of Yr17.

The adult plant resistance gene to stripe rust (Yr18) has also located on the same chromosome segment containing the Lr34 gene and is tightly linked with it (Mclntosh, 1992; Singh, 1992). Additionally, their co-segregation 
with other traits such as leaf tip necrosis (Ltn1), powdery mildew resistance gene (Pm38), and tolerance to barley yellow dwarf virus (Bdv1) has been reported (Mclntosh 1992; Liang et al., 2006; Singh, 1992; Spielmeyer et al., 2005). Therefore, this multi-pathogen resistance locus is a valuable source of resistance in wheat breeding (Urbanovich et al., 2006). The use of the slow rusting gene pair Lr34/Yr18 in combination with other slow rusting genes has been suggested to contribute to near immunity to leaf and stripe rust infections (Singh et al., 2000). In our finding Yr18 was present in all tested Egyptian and CIMMYT genotypes.

\section{REFERENCE}

Abu El-Naga, S. A.; M.M. Khalifa; S. Sherif; W.A.Youssef; Y.H. El-Daoudi. and I. Shafik (2001). Virulence of wheat stripe rust pathotypes identified in Egypt during 1999/2000 and sources of resistance. First Regional Yellow Rust Conference for Central \& West Asia and North Africa 8-14 May, SPH, Karj, Iran.

Afshari, F. (2004). Evaluation of Seedling and Adult Plant Resistance to Puccinia striiformis f.sp. tritici in Some Wheat Genotype. Second Yellow Rust Conference for Central and West Asia and North Africa. 22- 26 March, Islamabad, Pakistan. p. 22.

Bariana, H.S. and R.A. Mclntosh (1993). Cytogenetic studies in wheat. XV. Location of rust resistance genes in VPM1 and their genetic linkage with other disease resistance genes in chromosome 2Al Genome 36: 476-482.

Bariana, H.S. and R.A. Mclntosh (1994). Characterization and origin of rust and powdery mildew resistance genes in VPM1 wheat. Euphytica, 76: 53-61.

Bariana, H.S.; N. Parry; I.R. Barclay; R. Loughman, R.J. McLean, M. Shankar; R.E. Wilson; N.J. Willey and M. Franck (2006). Identification and characterization of stripe rust resistance gene Yr34 in common wheat. Theor. Appl. Genet., 112: 1143-1148.

Cao, Z.J.; M.N. Wang and J.X .Jing (2001). Progress in the inheritance of resistance to stripe rust in wheat. Triticeae Crops, 21:80-83.

Chen, X.M. (2005). Epidemiology and control of stripe rust [Puccinia striiformis f. sp. tritici] on wheat. Can. J. Plant Pathol., 273: 314-337.

Chen, X.M. and Zhao J. (2007). Identification of molecular markers for Yr8 and a gene for high-temperature, adult-plant resistance against stripe rust in the $A V S / 6^{*} Y r 8$ wheat line. American Phytopathological Society Abstracts, 97, S21.

Cheng, P. (2008). Molecular mapping of a gene for resistance to stripe rust in spring wheat cultivar IDO377 $\mathrm{s}$ and identification of a new race of Puccinia striiformis f.sp. tritici virulent on IDO377s. M.Sc. Thesis, Washington State University, Washington DC, USA Herrera-Foessel SA, Lagudah ES, Huerta-Espino J, Hayden M, Bariana HS. 
Eriksen, L.; F. Afshari; M.J. Christiansen; R. A. Mclntosh; A. Jahoor and C.R. Wellings (2004). Yr32 for resistance to stripe (yellow) rust present in the wheat cultivar Carstens V. Theor. Appl. Genet.,108: 567-575.

Fedak, G. (1999). Molecular aids for integration of alien chromatin through wide crosses. Genome, 42: 584-591.

Feuillet, C.; M. Messmer; G. Schachermayr and B. Keller (1995). Genetic and physical characterisation of the Lr1 leaf rust resistance locus on wheat (Triticum aestivum L.). Mol. Gen .Genet., 248: 553-562.

Friebe, B.; J.M. Jiang; W.J. Raupp; R.A. McIntosh and B.S. Gill (1996). Characterization of wheat alien translocations conferring resistance to diseases and pests: current status. Euphytica, 91: 59-87.

Fu, D.L.; C. Uauy; A. Distelfeld; A. Blechl; L. Epstein; X.M. Chen; H. Sela; T. Fahima and J. Dubcovsky (2009). A kinase-START gene confers temperature dependent resistance to wheat stripe rust. Science, 323: 1357-1360.

Helguera, M.; I.A. Khan; J. Kolmer; D. Lijavetzky; L. Zhong-qi and D. Ubcovsky (2003). PCR assays for the Lr37, Yr17 and Sr38 cluster of rust resistance genes and their use develop isogenic Hard Red spring wheat lines. Crop. Sci., 43: 1839-1847.

Hitta, L.; S. Manni and M. Foolad (1995). Development of PCR-based markers to identify rice blast resistance gene $\mathrm{Pi}-2 \mathrm{lt}$ in a segregating population. Theor. Appl. Genet., 91: 9-14.

Krattinger, S.G.; E.S. Lagudah; W. Spilmeyer; R.P. Sing; J. Huerta-Espinno; H. McFadden; E. Bossolini; L.L. Selter and B. Keller (2009). A putative $A B C$ trans-porter confers durable resistance to multiple fungal pathogen in wheat. Science, 323: 1360-1363.

Lagudah, E.S.; S.G. Krattinger; S. Herrera-Foessel; R.P. Singh; J. HuertaEspino; W. Spielmeyer; G. Brown-Guedira; L.L. Selter and B. Keller (2009). Gene-specific markers for the wheat gene Lr34/Yr18/Pm38 which confers resistance to multiple fungal pathogens. Theor. Appl. Genet., 119: 889-898.

Liang, S.S.; K. Suenaga; Z.H. He; Z.L. Wang; H.Y. Liu; D.S. Wang; R.P. Singh; P. Sourdille and X.C. Xia (2006). Quantitative trait loci mapping for adult-plant resistance to powdery mildew in bread wheat. Phytopathol., 96: 784-789.

Line, R.F. (2002). Stripe rust of wheat and barley in North America: a retrospective historical review. Annual Review of Phytopathol., 40: 75118 .

Lowe, L.; L. Jankuloski; S. Chao; X.M. Chen; D. See and J. Dubcovsky (2011). Mapping and validation of QTL which confer partial resistance to broadly virulent post-2000 North American races of stripe rust in hexaploid wheat. Theor. Appl. Genet., 123: 143-157.

Ma, J.X.; R.H. Zhou; Y.C. Dong; L.F. Wang; X.M. Wang and J.Z. Jia (2001). Molecular mapping and detection of the yellow rust resistance gene Yr26 in wheat transferred from Triticum Turgidum L. using microsatellite. Euphytica, 120: 219-226.

Mago, R; W. Spielmeyer; G.J. Lawrence; E.S. Lagudah; J.G. Ellis and A. Pryor (2002). Identification and mapping of molecular markers linked 
to rust resistance genes located on chromo-some 1RS of rye using wheat-rye translocation lines. Theor. Appl. Genet., 104: 1317-1324.

Maia, N. (1967). Obtention des bles tendres resistant au pietin-verse par croisements inter specific bles Aegilops. C.R. Acad. Agric. (Fr.) 53:149-154.

Mclntosh, R.A. (1992). Close genetic linkage of genes conferring adult-plant resistance to leaf rust and stripe rust in wheat. Plant Pathol., 41: 523527.

McIntosh, R.A.; J. Silk and T.T. The (1996). Cytogenetic studies in wheat XVII Monosomic analysis and linkage relationships of gene Yr15 for resistance to stripe rust. Euphytica, 89: 395-399.

Mclntosh, R.A.; G.E. Hart; K.M. Devos and W.J. Rogers (2004). Catalogue of gene symbols for wheat: 2004 supplement.

McIntosh, R.A.; K.M. Devos; J. Dubcovsky and W.J. Rogers (2005). Catalogue of gene symbols for wheat: 2005 supplement.

McNeal F.H.; C.F. Konzak; E.P. Smith; W.S. Tate and T.S. Russell (1971). A uniform system for recording and processing cereal research data. U.S. Dept. Agric., Agric. Res. Serv., Washington, D.C., ARS, 34-121. 42 pp.

Mukhtar, M.S.; M. Rehman and Y. Zafar (2002). Assessment of genetic diversity among wheat (Triticum aestivum $\mathrm{L}$ ), cultivars from a range of localities across Pakistan using random amplified polymorphic DNA (RAPD) analysis. Euphytica, 128: 417-425.

Peng, J.H; T. Fahima; M.S. Röder and Y.C. Li (1999). Microsatellite tagging of the stripe-rust resistance gene $\mathrm{YrH} 52$ derived from wild emmer wheat, Triticum dicoccoides, and suggestive negative cross over interference on chromosome 1B. Theor. Appl. Genet., 98: 862-872.

Peng, J.H,; T. Fahima; M.S. Röder and Q.Y. Huang (2000-a). High density molecular map of chromosome region harboring stripe-rust resistance genes $\mathrm{YrH} 52$ and $\mathrm{Yr} 15$ derived from wild emmer wheat. Triticum dicoccoides. Genetica, 109: 199-210.

Peng, J. H.; T. Fahima; M.S. Roder; Y.C. Li; A. Grama and E. Nevo (2000-b). Microsatellite high-density mapping of the stripe rust resistance gene $\mathrm{YrH} 52$ region of chromosome 1B and evaluation of its marker-assisted selection in the F2 generation in wild emmer wheat. New Phytol. 146: 141-154.

Peterson, R.F.; A.B. Campbell and A.E. Hannah (1948). A diagrammatic scale for estimating rust intensity on leaves and stems of cereals. Can. J. Res., 60: 496-500.

Ren, R.S.; M.N. Wang; X.M. Chen and Z.J. Zhang (2012). Characterization and molecular mapping of Yr52 for high-temperature adult-plant resistance to stripe rust in spring wheat germplasm PI 183527. Theor. Appl. Genet., 125: 847-857.

Roelfs, A.P., R.P. Singh and E.E. Saari (1992). Stripe rust. In: Rust diseases of wheat: Concept and methods of disease management. (Ed.): G.P. Hettel. Mexico, D.F.: CIMMYT Mexico. pp. 23-24.

Singh R.P. (1992). Genetic association of leaf rust resistance gene Lr34 with adult plant resistance to stripe rust in bread wheat. Phytopathol., 82: 835-838 
Singh, R.P., Nelson, J.C. and Sorrells, M.E. (2000). Mapping Yr28 and other genes for resistance to stripe rust in wheat. Crop Sci., 40: 1148-1155. Somers D.J., Isaac.

Spielmeyer, W., McIntosh, R.A.; Kolmer, J. and E.S. Lagudah (2005). Powdery mildew resistance and $L r 34 / Y r 18$ genes for durable resistance to leaf and stripe rust cosegregate at a locus on the short arm of chromosome 7D of wheat. Theor. Appl. Genet., 111: 731-735.

Stakman, E.C.; D.M. Stewart and W.Q. Loegering (1962). Identification of physiologic races of Puccinia graminis tritici. ARS, USDA, Agric. Res. Serv. Bull. E-617. 53 pp.

Stubbs, R.W. (1988). Pathogenicity analysis of yellow (stripe) rust of wheat and its significance in a global context. In: Breeding Strategies for Resistance to the Rusts of Wheat. N. W. Simmonds, S. Rajaram (Eds). Mexico DF (CIMMYT) Mexico.:96-127.

Sun, G.L., T. Fahima; A.B. Korol; T. Turpeinen; A. Grama; Y.I. Ronin and E. Nevo (1997). Identification of molecular markers linked to the Yr15 stripe rust resistance gene of wheat originated in wild emmer wheat, Tritium dicoccoides. Theor. Appl. Genet., 95: 622-628.

Sun, Q.X., Y.L. Wei; C. Ni; C. Xie and T. Yang (2002). Microsatellite marker for yellow rust resistance gene $Y r 5$ in wheat introgressed from spelt wheat. Plant Breed., 121: 539-541.

Tervet, I. and R.C. Cassell (1951). The use of cyclone separation in race identification of cereal rusts. Phytopathol., 41: 282-285.

Urbanovich, O.Y., S.V. Malyshev; T.V. Dolmatovich and N.A. Kartel (2006). Identification of leaf rust resistance genes in wheat (Triticum aestivum L.) cultivars using molecular markers. Russ. J. Genet., 42: 675-683.

Wang, L.F.; J.X. Ma; R.H. Zhou; X.M. Wang and J.Z. Jia (2002). Molecular tagging of the yellow rust resistance gene (Yr10) in common wheat Pll78382 (Triticm aestivum ). Euphytica, 124:71-73.

Zakari, A.; R.A. McIntosh; M.S. Hovmoller; C.R. Wellings; M.R. Shariflou; M. Hayden and H.S. Bariana (2003). Recombination of Yr15 and Yr24 in chromosome 1BS. In: Pogna, N.E., Romano, N., Pogna, E.A., Galterio,G. (eds.), Proc. 10th Int. Wheat Genet. Symp. Instituto Sperimentale per la Cerealcoltura, Rome 1: 417-420.

Zeller, F.J. (1973). 1B.1R Wheat-rye Chromosome Substitutions and Translocations. In: Proceedings of the Fourth International Wheat Genetics Symposium. University of Missouri, Columbia, U.S.A. 209221. 


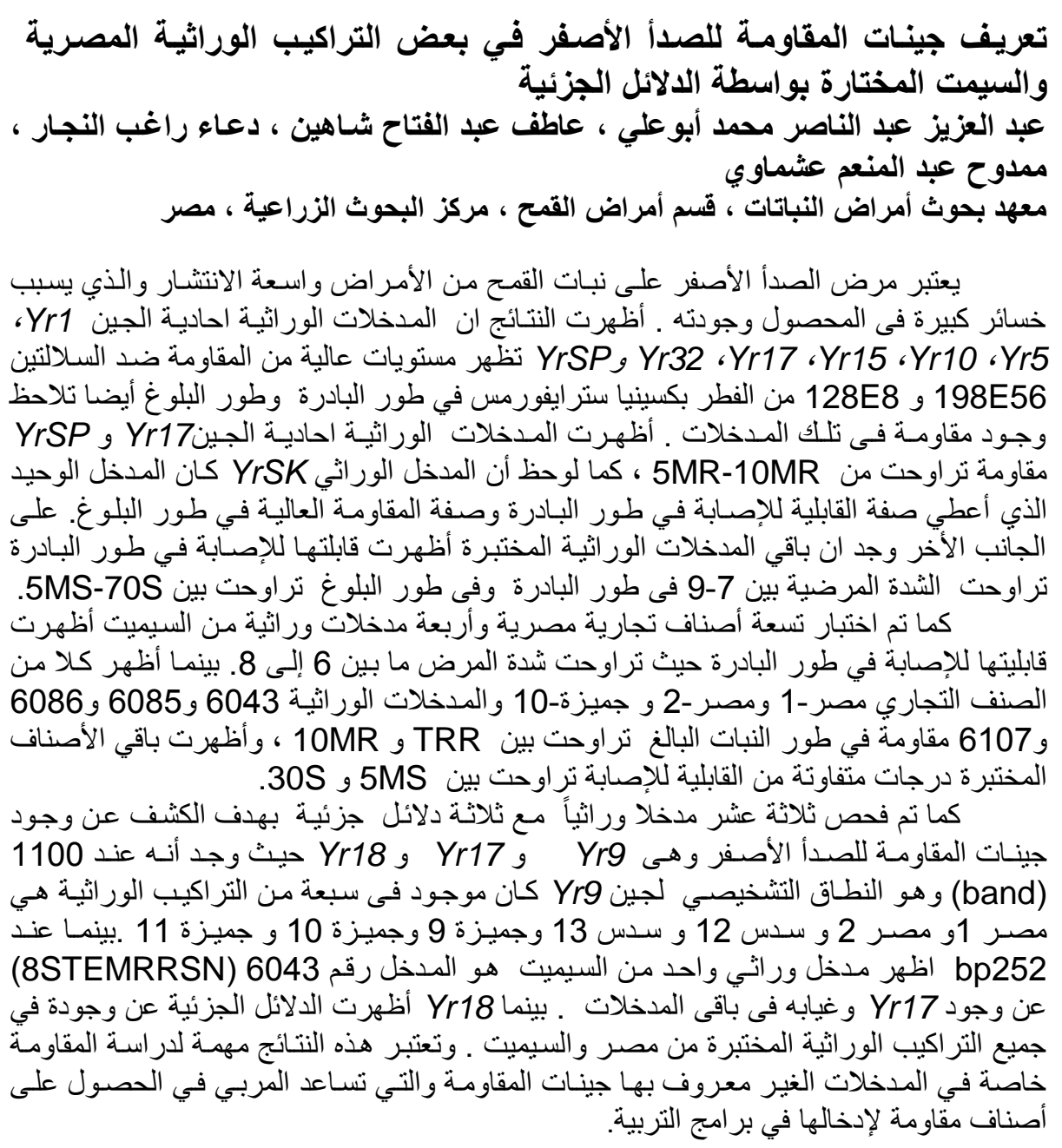

